of its relation to chlorophyll and to vitamins. Prof. R. Robinson discusses in some detail the structures of anthocyanins, the red and blue colouring matter of flowers. Prof. R. Kuhn refers to the influence of Willstätter's work on the development of the theory of heteropolar rings, and Dr. Waldschmidt-Leitz describes the process of resolution of enzyme mixtures from the pancreas and from yeast by a method of selective adsorption. The concluding article upon chlorophyll and its derivatives is by Prof. A. Stoll and Dr. E. Wiedemann.

\section{A New Periodical for Chemical Physics}

As a part of its comprehensive programme of physics publications, the recently formed American Institute of Physics (see Nature for Aug. 6, p. 199) announces that it will shortly begin a new publication to be called the Journal of Chemical Physics. The first number will be issued in January 1933. Primary among the circumstances which have led the Institute to undertake the new publication is the increasing number of articles on physical chemistry which have distinct bias on the physical side. These have not found a suitable outlet in any journal now in existence, being perhaps too mathematical for the Journal of Physical Chemistry, too physical for the Journal of the American Chemical Society, or too chemical for the Physical Review. Inquiries or suggestions concerning the new journal should be addressed either to Dr. Harold C. Urey, Department of Chemistry, Columbia University, or to the American Institute of Physics, 11 East 38th Street, New York.

\section{Irrigation in India}

THE progress of irrigation and the use of the available water are surveyed in the "Triennial Review of Irrigation in India, 1927-30" (Simla: Government Press, 2s. 6d.). It would appear that the monsoon of 1927 was almost normal in its time and rainfall except for a slight deficit. In 1928 there was a marked deficiency in the north-west, and in 1929 the principal departure from the average was an excess of 100 per cent in the rainfall of the North-West Province and Sind. During the three years under review, the average area irrigated by Government works in British India was 29,954,000 acres, an advance of more than two million acres on the corresponding figure for the previous triennium. The chief increase was in the Punjab valley, owing to the development on the Sutlej valley canals. It is noticeable that, of the total sown area, 12.7 per cent was irrigated. Among the most important projects now in hand are the Sukkur Barrage and canals in Sind, the Sarda canal and a hydro-electric power scheme on the Ganges canal in the United Provinces, and the Sutlej valley project in the Punjab. The problems of water supply in Baluchistan are being considered in the hope of improving the very poor irrigation facilities.

\section{Commonwealth of Australia Yearbook}

THE Yearbook of the Commonwealth of Australia for 1931 contains a mass of descriptive and statistical matter, of which much is of considerable scientific value. The prevalent demand for economy has curtailed to some extent the size of the volume, but there is little evidence of its usefulness being impaired. The figures dealing with agricultural production are particularly full, vital statistics are given much space, and there is a long article, accompanied by distributional maps, on the climate and meteorology of Australia.

\section{Announcements}

Prof. R. Rugales Gates will deliver three De Lamar lectures at the Johns Hopkins University during the week beginning Oct. 24, on "The Principles of Heredity in Man, and their Application to Society".

Ir is announced in Science that Prof. Rudolph W. Ladenburg, of the Kaiser Wilhelm Institut für physikalische Chemie und Elektrochemie, has been appointed to the Cyrus Fogg Brackett research professorship at Princeton University, in physics.

THe Society for Cultural Relations with Soviet Russia is considering the possibility of arranging a tour of scientific institutions in Russia, to leave London on Sept. 10. It is proposed to arrange for parties of British scientific workers engaged in physical, biological, and medical research, and for engineers, chemists, and anthropologists, to visit the corresponding institutions in Russia, and to meet Russian workers engaged in similar research. The total cost of the tour is about $£ 35$ inclusive, the time being approximately one month from departure to return to London. Further particulars and application forms may be obtained from the Secretary, S.C.R., 1 Montague Street, London, W.C.I.

Messrs. W. and G. Foyle, Ltd., of 119-125 Charing Cross Road, W.C.2, have recently published a new catalogue of new and second-hand books on technical subjects and applied sciences. More than 450 subjects are represented. About three thousand books are catalogued, and the list should prove a source of help. The majority of the standard works are available, many of them being obtainable second-hand as well as new.

Applicatrons are invited for the following appointments, on or before the dates mentioned:-A headmaster for the Netherton Farm School, near Morpeth, Northumberland-The Secretary, 18 City Road, New. castle-on-Tyne (Sept. 3). An assistant conservator of forests in the Department of Agriculture and Forests, Sudan Government-The Controller, Sudan Government London Office, Wellington House, Buckingham Gate, S.W.1 (Sept. 5). A professor of zoology at the University of Bristol-The Secretary and Registrar (Oct. 1). A resident tutor of chemistry, rural science, and school hygiene at the Winchester Diocesan Training College-The Principal. A headmaster of the Incorporated Thames Nautical Training College, H.M.S. Worcester-The Secretary, Ingress Abbey, Greenhithe, Kent. An assistant (woman), with analytical experience in organic and inorganic work, at the Air Ministry, Kidbrooke-The Secretary, (I.G.), Air Ministry, W.C.2.

$$
\text { No. 3278, VoL. 130] }
$$

